\title{
Literacy comes second: Working with groups in developing societies
}

\section{Alan Rogers}

To cite this article: Alan Rogers (2000) Literacy comes second: Working with groups in developing societies, Development in Practice, 10:2, 236-240, DOI: 10.1080/09614520050010287

To link to this article: https://doi.org/10.1080/09614520050010287

里 Published online: 01 Jul 2010.

Submit your article to this journal 지

Џ Article views: 129

Citing articles: 14 View citing articles 5 
displaced from the countryside into Izmit. The devastation was such that many people ended up living in tents, drawing water from standpipes. The village of Yuvacik survived, and also the dam, which had been constructed of earth and rubble. Much of the water supply system was destroyed, and it seems unlikely that the US\$847 million invested will be recovered in the 15 -year life of the project. Had the people who migrated to Izmit remained in the countryside, their chance of surviving the earthquake would have been better. The Gulf of Izmit suffered extensive devastation, and the population group most severely affected was those who had been displaced from the countryside, and were living in multi-storey apartments. If such tragedies are to be avoided, perhaps greater attention should be given to re-housing inhabitants displaced by development, and perhaps there is a need to strengthen international law.

\section{The author}

Dennis Paling is affiliated to the Refugee Study Centre at the University of Oxford. Contact details: 22 Telford Way, High Wycombe HP13 5EE, UK.

\section{Literacy comes second: working with groups in developing societies}

\section{Alan Rogers}

The scene is a women's literacy group in India (or for that matter in Bangladesh or Pakistan - in this respect, they are much the same). There are 30 women on the register, about 25 in attendance. It meets at a time agreed by the participants (usually afternoon or early evening) and in a central place in the village (often the house of the literacy instructor, facilitator, or animator) which has also been chosen by the participants. The sessions last for about two hours. Most of the time is spent by the learners working individually on the textbook (the literacy primer) exercises, the rest on discussion of some common matter (not every group has this discussion element, but virtually every group is intended to have it). They are all working on the same page, at the same point-there is little difference between all the learners during the class. Many of them leave the primer (and sometimes even their own exercise books) at the class centre, others take them home until the next meeting. From time to time, a supervisor comes from the NGO or government agency providing the literacy class - to check up on the attendance or the teaching of the instructor, just like a school inspector. At the end of the nine months (or whatever length of time is set for the programme), the participants are invited to sit a test to see if they have become 'literate'.

\section{Traditional adult literacy pro- grammes}

This is typical of most adult literacy programmes. The majority are for women, but there are in every country significant numbers of classes for men, on the same model but usually meeting after dark. It is worth looking in more detail at this kind of programme to see its chief elements.

The main characteristic of the group which has been formed for this purpose is that it is an artificial group. It has been created by the providing agency (whether government or NGO), usually by asking the chosen facilitator/instructor to identify and to motivate the participants. Numbers have normally been set at about 30 learners, although several more recent programmes have gone for smaller groups; the volunteers 
of the Indian Total Literacy Campaign were asked to find about ten or so illiterates to teach. All the participants are people who have been defined (or who have defined themselves) as 'illiterate' —as not having been to primary school or as having dropped out from primary school before they have mastered the skills of reading and writing any texts. There are known cases of people who have some literacy skills being turned away from the group.

These groups (especially the women's groups) are often highly valued by the participants. In a recent survey in Nepal of local demand for post-literacy provision after the completion of the first set of textbooks, the women asked said that they wanted more classes, more textbooks to work on. But an analysis of the reasons for this reveals that it is the non-literacy benefits rather than the literacy elements which are most valued. The participants like the discussions which open their minds to new things. They value the opportunity to get out of the house, to meet with others, to talk about community happenings and concerns. They feel a sense of solidarity which was lacking before the group existed. They feel more confident and independent. And these groups often lead on to some other form of activity-some programme of income generation like sewing or social development such as latrine building.

It was the literacy programme which in this case created the group. This was not an already existing group; it is new. It is in this sense that many agencies in these countries, following the rhetoric of UNESCO, talk about literacy being the key to development, the entry point, the start to a programme of self-directed improvement. This is a 'literacy comes first' model: learn literacy first, and then engage in some form of developmental activity.

But this model also has some problems. First, the main inspiration is that of primary school; it is a classroom model. The learners are seen as being all at the same level (all illiterates), and they are all treated the same, not each of them as being at different levels or having different concerns. Indeed, they have been picked out of the community because they are illiterate. They are made to feel different from the other community members. With the stress being laid on motivating them to the need for learning literacy, they are often made to feel that they have a deficit, that they are not and cannot be useful members of the community until they have 'become literate'.

And, although most agencies try to keep some parts of the programme flexible, with the participants saying when and where they want to meet, the remainder is formal-a pre-set curriculum, with a planned sequence of learning and a textbook. Each of the learners learns on his or her own; there are no shared tasks (there is very little use of small group work in adult literacy classes). The school-based attitude to education is paramount here-learn first and then do later, rather than the adult learning approach of 'learn through doing'.

Such an approach to adult literacy is now widely accepted as being more effective for the indirect benefits it brings rather than for its primary purpose of increasing literacy skills. Relatively few persons learn literacy skills effectively through this model; and many of those who do are not able to transfer their newly acquired literacy skills from the classroom/centre into use outside the classroom, in the community, at home, or at work. It is for this reason that new approaches to adult literacy are being sought in many different parts of the world.

\section{'Literacy comes second'}

One such approach which is being experimented with may hold greater promise for the future than the traditional literacy classes. This is to work with groups which already exist in the community (natural rather than artificial groups). Many villages throughout the Indian subcontinent already have mahila mandals (women's groups); and men's groups also exist on occasion. 
Religious groupings, groups meeting for business purposes, residents' groups, especially in urban areas, local government and political groups and the like often exist in villages. Or there are many developmental groups which have already been formed for a variety of purposes-social or economic development or cultural activities and so on. Most of these are for some form of incomegeneration programme, and several have been in existence for many years.

The main characteristic of these groups is that, from the point of view of literacy, they are mixed groups, consisting of men or women (they are rarely mixed-sex groups) who have different levels of literacy skills, so that such a group is more representative of the community as a whole, unlike the literacy class. Non-literate persons can and do join such groups; they feel useful, not useless. On occasion, non-literate persons take the lead: several women's groups in Bangladesh are led by women who are entirely non-literate. The group members share their skills and experiences; every member is valued. And they have a common task. They are not there simply for each individual to increase his/her skills; they work together for a joint purpose.

It is therefore possible for literacy agencies to work not only with newly formed groups (classes) of illiterates, but also with existing groups which are mixed in their literacy skills and which have a primary aim of some developmental, economic, or social task of their own. Literacy training would then be added onto the range of training and support programmes made available to these groups. But this literacy training provision would not be confined to the non-literate members but made available to everyone in the group. And it would be done, not through taking the illiterates away and putting them through a classroom teaching programme with a textbook, but through the whole group sharing literacy skills and using its own work as the basis for learning literacy skills.

There are several examples of such groups. One which has been quoted many times is the project at Banda, in North India, where a group of women came together to learn how to mend and maintain their own water hand-pumps. Some of the women were relatively advanced in literacy skills, others were completely non-literate. The group as a whole learned enhanced literacy skills through the hand-pump manual, and the members began to write their own newsletter. There are other examples. In Tamil Nadu, a group of women who worked in a quarry took over the lease of the quarry; and they all worked together to develop the skills they needed (including literacy) to do this task. In Nepal, a group of women (some of whom were completely non-literate) engaged in a sewing consortium increased their literacy skills through the sewing books. In Bangladesh, a group of men running a small tempo (taxi) service also worked on their literacy skills in relation to their work. Several savings and credit groups learned literacy skills through keeping records of their group activities.

The justification for this approach comes from adult learning theory, which says that adults (as distinct from children) learn best through doing things in their own lives for real-that they learn cooking by (real) cooking, they learn farming by (real) farming, they learn parenting by parenting, they learn literacy skills by using literacy for real. It is not a 'learn first, then do' model, but a 'learn through doing for real'.

And the motivation for learning literacy skills comes from the real tasks they are engaged on. They want to learn to write the group's loans accounts; they want to learn to read the sewing patterns or hand-pump manual, to apply for a ration card for group members, to fill in a health census form, etc.

It is sometimes argued that such material (accounts and training manuals and bank or government forms) are too difficult for adults to use for learning. But there are two answers to this. First, adults do not find things difficult when they really want to do them. They can cope with even a difficult form when they understand its meaning and 
when it is important to them to do so. For example, a women's group in Bangladesh, engaged in a campaign about violence against women, learned to read and use several legal texts simply because they were very concerned about this issue; and in India, a residents' group in Madras (Chennai) learned to cope with literacy activities related to council matters and in the process the literacy skills of the members of the group were enhanced. And second, these non-literate adults find themselves in a supportive environment, with other adults who have more skills than they do, adults moreover who want to help them to learn. The 'teaching' is not left to a facilitator or instructor; it is shared among all the group members.

And literacy is seen here as it really is - one of a number of useful skills which any group needs to have to do its work satisfactorily. There are other skills-skills of decision making and of assessing risks, craft skills, skills of running a committee meeting, of keeping records of decisions made, of planning and managing projects, skills of monitoring and evaluating the group's activities and of dealing with bureaucratic officials, etc. All these skills exist to some extent within such a developmental group; but equally all these skills will be learned further and enhanced in the group as a whole as its work progresses. The supporting government agency or NGO will seek to help the group to improve on all its skills, including its literacy skills.

Such an approach can be developed in many fields. One example is work-based literacy, where groups of workers from one concern are helped to improve their literacy skills, a programme which is expanding rapidly in many developing countries. But in most work-based literacy programmes, there is a tendency to fall back on the traditional approach - to separate out 'the illiterates' from their colleagues, and to put them into a class solely of illiterates; to take them away from their work environment into special classrooms; to use for learning material a pre-set textbook/primer which has very little to do with their specific workplace rather than the notices and instructions and other texts they are expected to be able to read or write during the course of their work. It is a 'learn first and do later' model. An approach which starts from developing the work skills of all the workers (not just the non-literate workers) in general, and which includes literacy as part of these skills, is likely to be more effective. Separating illiterates from their immediate colleagues is almost certain to prove harmful to the adult learning programme.

The main differences between the 'literacy comes second' approach and that of the traditional adult literacy class is shown in Table 1 (see next page).

This approach holds a good deal of promise in that it will lead to people not only learning to be able to read and write but in fact using literacy skills to achieve developmental tasks. A lot more experimental work in this area needs to be undertaken, carefully monitored and evaluated, and its fruits disseminated to see if it will yield its apparent potential to achieve real advances in literacy activities in the towns and villages of developing countries.

\section{Further reading}

Fordham, Paul, Deryn Holland and Juliet Millican (1995) Adult Literacy: A Handbook for Development Workers, Oxford: Oxfam/ VSO.

Rogers, Alan (1994) Women, Literacy, Income-generation, Reading: Education for Development.

\section{The author}

Alan Rogers was until April 1998 Executive Director of Education for Development, a specialist agency in adult learning in development programmes. $\mathrm{He}$ has spent more than 25 years working in adult education in developing countries (especially India and Bangladesh). Contact details: Noel Close, 5 Adderley Street, Uppingham, Rutland LE15 9PP, UK. E-mail: $<$ alan.rogers@nottingham.ac.uk >. 
Table 1: Differences between the 'literacy comes first' and 'literacy comes second' approaches

\begin{tabular}{|c|c|c|}
\hline & $\begin{array}{l}\text { Traditional 'literacy comes first' } \\
\text { model }\end{array}$ & $\begin{array}{l}\text { 'Literacy comes second' } \\
\text { model }\end{array}$ \\
\hline Members of group & $\begin{array}{l}\text { A group whose members are all } \\
\text { illiterate }\end{array}$ & $\begin{array}{l}\text { A mixed group of persons } \\
\text { who have different levels } \\
\text { of literacy skills; some } \\
\text { non-literates }\end{array}$ \\
\hline Size of group & $\begin{array}{l}\text { Set artificially by the providing } \\
\text { agency (e.g. } 30 \text { or other set number } \\
\text { of learners) }\end{array}$ & $\begin{array}{l}\text { An open group, or the } \\
\text { limit to numbers is } \\
\text { determined by the group } \\
\text { members }\end{array}$ \\
\hline $\begin{array}{l}\text { Primary objective } \\
\text { of group }\end{array}$ & $\begin{array}{l}\text { Literacy learning; other activities } \\
\text { (discussion, income generation, } \\
\text { etc.) are secondary }\end{array}$ & $\begin{array}{l}\text { Its common and shared } \\
\text { developmental task }\end{array}$ \\
\hline Attitude to literacy & Literacy is its main objective & $\begin{array}{l}\text { Literacy is secondary to } \\
\text { the task }\end{array}$ \\
\hline Process & $\begin{array}{l}\text { Learning is individual and only } \\
\text { from instructor/facilitator }\end{array}$ & $\begin{array}{l}\text { Learning is collaborative; } \\
\text { the group members help } \\
\text { each other }\end{array}$ \\
\hline Learning materials & $\begin{array}{l}\text { Specially written textbooks } \\
\text { (primers) }\end{array}$ & $\begin{array}{l}\text { The materials of the } \\
\text { group's activities }\end{array}$ \\
\hline
\end{tabular}

The Participatory Change

Process: a capacity building model from a US NGO

\section{Paul Castelloe and Thomas Watson}

\section{Introduction}

This paper describes the Participatory Change Process (PCP), a new practice model that promotes the formation and action of sustainable grassroots organisations in poor and marginalised communities. ${ }^{1}$ This model uses participatory learning and action methods to provide people with the capacities, self-confidence, and organisational structures needed to plan and implement development projects and influence policy formation. The
Participatory Change Process was developed by the Center for Participatory Change, a US NGO that nurtures the development of grassroots organisations in western North Carolina.

\section{Core concepts in the Participatory Change Process}

At the core of the PCP are the concepts of participation and capacity building. Participation occurs when people use their life experiences as the foundation for community assessment, the analysis of community issues, and the planning and implementation of projects to address those issues (Chambers 1997). It refers to a process whereby community members control their community's development, shape the policies that effect it, and influence its direction of change (Nelson and Wright 1995). Capacity building refers 